\title{
Pengaruh Kepemimpinan Transformasional, Komunikasi Organisasi Dan Budaya Organisasi Terhadap Kinerja Pegawai Pegawai Dinas Kesehatan Kota (Dkk) Padang
}

\author{
Bayu Pratama Azka \\ Universitas Putra Indonesia YPTK Padang, Indonesia \\ bayupratamaazka@upiyptk.ac.id
}

\begin{abstract}
Abstrak
Penelitian ini bertujuan Untuk mengetahui dan menganalisa pengaruh kepemimpinan transformasional, komunikasi organisasi dan budaya organisasi terhadap kinerja Pegawai Pegawai Dinas Kesehatan Kota (DKK) Padang. Populasi dalam penelitian ini adalah seluruh pegawai Dinas Kesehatan Kota (DKK) Padang. Sampel dalam penelitian ini ialah 110 pegawai pada Dinas Kesehatan Kota (DKK) Padang. Analisis data yang dilakukan adalah dengan menggunakan uji validitas, reliabilitas, asumsi klasik, regresi linear berganda, Uji F dan Uji t. Pengujian tersebut dilakukan guna untuk mengetahui pengaruh variabel terhadap varibel terikat.

Berdasarkan hasil penelitian ini menemukan bahwa Kepemimpinan Transformasional, Komunikasi Organisasi Dan Budaya Organisasi berpengaruh positif dan signifikan terhadap kinerja Pegawai pegawai Dinas Kesehatan Kota (DKK) Padang.
\end{abstract}

Kata Kunci : Kepemimpinan transformasional, Komunikasi Organisasi, Budaya Organisasi, dan Kinerja Pegawai pegawai

\section{Pendahuluan}

Dalam sebuah organisasi agar dapat berkembang dan maju sangat tergantung dari kinerja Pegawai pegawai itu sendiri. Apabila kinerja Pegawai juga tercapai dengan baik, namun sebaliknya apabila kinerja Pegawai pegawai tidak bagus maka hasil yang diperoleh juga tidak baik sehingga tujuan yang diinginkan oleh organisasi tidak dapat tercapai dengan maksimal. Untuk itu perhatian dari pimpinan kantor untuk memenuhi kebutuhan pegawai, agar kinerja Pegawai pegawai bagus. Pegawai yang memiliki kinerja Pegawai yang baik akan senantiasa melakukan perubahan ke arah yang lebih baik.

Mengacu pada penting nya peningkatan kinerja pegawai pada Dinas Kesehatan Kota Padang, peneliti mengambil penelitian di Dinas Kesehatan kota (DKK) Padang, merupakan salah satu perangkat pemerintahan kota Padang yang bertanggung jawab atau kesehatan masyarakat kota padang itu sendiri dibawah pengawasan Dinas Kesehatan.

Dinas Kesehatan Kota (DKK) Padang yang beralamatkan Jl. Bagindo Aziz Chan By Pass Aia Pacah Padang. Dinas Kesehatan Kota dipimpin oleh seorang kepala dinas. Visi dari Dinas Pembangunan Kesehatan Kota Padang yakni “ Mewujudkan Mayarakat Kota Padang Peduli Sehat, Mandiri, Berkualitas dan Berkeadilan Tahun 2019”. Salah satu misi Dinas Kesehatan Kota (DKK) padang adalah Meningkatkan derajat kesehatan masyarakat melalui pemberdayaan masyarakat, termasuk swasta dan masyarakat madani.

Tabel 1

Indikator Kinerja Pegawai Standar Pelayanan minimal (SPM) DKK Padang Tahun 2015-2016

\begin{tabular}{|c|c|c|c|}
\hline No & Nama Indikator & \multicolumn{2}{|c|}{ Hasil Realisasi } \\
\cline { 3 - 4 } & & $\mathbf{2 0 1 5}$ & $\mathbf{2 0 1 6}$ \\
\hline 1 & Cakupan komplikasi kebidanan yang ditangani & $\mathbf{4 1 , 7 1 \%}$ & $\mathbf{7 0 , 0 1 \%}$ \\
\hline 2 & Cakupan desa/ kelurahan Universal Child & $\mathbf{6 8 , 2 7} \%$ & $\mathbf{6 8 , 2 7} \%$ \\
\hline
\end{tabular}




\begin{tabular}{|c|l|c|c|}
\hline 3 & $\begin{array}{l}\text { Cakupan pelayanan kesehatan rujukan pasien } \\
\text { masyarakat miskin }\end{array}$ & $\mathbf{3 , 5 5} \%$ & $\mathbf{1 4 , 1 8 \%}$ \\
\hline 4 & Cakupan desa siaga aktif & $\mathbf{1 0 0} \%$ & $\mathbf{3 7 , 5} \%$ \\
\hline
\end{tabular}

Sumber: laporan tahunan Dinas Kesehatan kota (DKK) Padang tahun 2016 edisi 2017

Berdasarkan Tabel 1.1 diatas terlihat fluktuasi tingkat pencapaian kinerja SPM DKK Padang, pada indikator pertama pada tahun 2015 pencapaian sebesar $41,71 \%$ sedangkan pada tahun 2016 terjadi peningkatan sebesar 70,01 \%. Pada indikator kedua pada tahun 2015 pencapaiannya sebesar 68,27\% sedangkan pada tahun 2016 tidak terjadi peningkatan dan tetap pada 68,27\%. Pada indikator ketiga pencapaiannya sebesar 3,55\% sedangkan pada tahun 2016 terjadi peningkatan pencapaian sebesar 14,18. Pada indikator keempat pada tahun 2015 tercapai dengan sempurnya sebesar 100\% sedangkan pada tahun 2016 terjadi penurunan yang besar sebesar 37,5\%. Dari Perolehan data diatas maka dapat di lihat bahwa tingkat pencapaian kinerja SPM DKK Padang masih rendah dan tidak mendekati target pencapaian kinerja tertinggi.

\section{Metodologi Penelitian}

Objek Penelitian

Kegiatan penelitian ini akan dilakukan pada Dinas Kesehatan Kota (DKK) Padang. beralamatkan J1. Bagindo Aziz Chan By Pass Aia Pacah Padang.

\section{Desain Penelitian}

Pada penelitian ini menggunakan metode kuantitatif, menurut Sugiyono (2014:8), metode kuantitatif adalah metode yang berlandasan pada filsafat positifisme, digunakan untuk meneliti pada populasi dan sampel tertentu, pengumpulan data menggunakan instrumen penelitian, analisis data bersifat kuantitatif/statistik dengan tujuan untuk menguji hipotesis yang telah ditetapkan.

\section{Popupasi dan Sampel}

Menurut Umar (2013:77), populasi adalah wilayah generalisasi yang terdiri atas objek atau subjek yang mempunyai karakteristik tertentu dan mempunyai kesempatan yang sama untuk dipilih menjadi anggota sampel.. Sedangkan sampel Menurut Umar (2013:26), sampel adalah bagian dari populasi yang mewakili populasi yang secara mutlak tidak diketahui berapa persentase sampel tersebut akan tetapi minimal 30 responden.. Dalam penelitian ini tidak menggunakan teknik sampling karena sampel yang diteliti adalah keseluruhan dari populasi yang ada sebanyak 110 orang.

\section{Hasil Dan Pembahasan}

Hasil Uji Regresi Berganda

Tabel 2. Coefficients

\begin{tabular}{|c|c|c|c|c|c|c|}
\hline \multirow{2}{*}{\multicolumn{2}{|c|}{ Model }} & \multicolumn{2}{|c|}{$\begin{array}{l}\text { Unstandardized } \\
\text { Coefficients }\end{array}$} & \multirow{2}{*}{$\begin{array}{l}\text { Standardized } \\
\text { Coefficients }\end{array}$} & \multirow[b]{2}{*}{$\mathrm{t}$} & \multirow[b]{2}{*}{ Sig. } \\
\hline & & B & Std. Error & & & \\
\hline 1 & (Constant) & 14,523 & 2,785 & & 5,215 & ,000 \\
\hline & $\begin{array}{l}\text { Kepemimpinan } \\
\text { Transformasional }\end{array}$ & ,434 & ,045 & ,573 & 9,585 & ,000 \\
\hline & Komunikasi & ,044 &, 022 & ,115 & 2,004 & ,048 \\
\hline & Budaya Organisasi & ,212 & ,032 & ,404 & 6,665 & ,000 \\
\hline
\end{tabular}

Sumber: Hasil Pengolahan Data Primer, SPSS for windows version 21.0

Berdasarkan tabel di atas maka dapat dilihat persamaan regresinya sebagai berikut :

$$
\begin{aligned}
& \mathrm{Y}=\mathrm{a}+\mathrm{bX} \mathrm{X}_{1}+\mathrm{bX} \mathrm{X}_{2}+\mathrm{bX} \mathrm{X}_{3}+\mathrm{e} \\
& \mathrm{Y}=14,523+0,434 \mathrm{X}_{1}+0,044 \mathrm{X}_{2}+0,212 \mathrm{X}_{3}
\end{aligned}
$$


Tabel 3. Uji Hipotesis

Pengujian Hipotesis Secara Parsial (Uji t)

\begin{tabular}{|c|l|l|c|c|}
\hline No & Variabel Independen & \multicolumn{1}{c|}{$\mathrm{t}_{\text {hitung }}$} & $\mathrm{t}_{\text {tabel }}$ & Sig \\
\hline 1 & $\begin{array}{l}\text { Kepemimpinan } \\
\text { Transformasional }\end{array}$ & 9,585 & 1.65936 &, 000 \\
\hline 2 & Komunikasi Organisasi & 2,004 & 1.65936 &, 048 \\
\hline 3 & Budaya Organisasi & 6,665 & 1.65936 &, 000 \\
\hline
\end{tabular}

Sumber: Hasil Pengolahan Data Primer, SPSS for windows version 21.0

Berdasarkan Tabel diatas dapat kita lihat lihat bahwa seluruh tingkat signifikan dari semua variabel yaitu <0,050, maka dapat disimpullkan bahwa Ho di tolak dan Ha diterima. Maka masing-masing variabel secara parsial berpengaruh terhadap Y.

Tabel 4. Pengujian Hipotesis Secara Simultan (Uji F)

\begin{tabular}{|c|c|c|c|c|c|}
\hline \multicolumn{6}{|c|}{ ANOVAa } \\
\hline Model & $\begin{array}{c}\text { Sum of } \\
\text { Squares }\end{array}$ & df & $\begin{array}{l}\text { Mean } \\
\text { Square } \\
\end{array}$ & $\mathrm{F}$ & Sig. \\
\hline 1 Regression & 4076,469 & 3 & 1358,823 & 68,770 & $.000 \mathrm{~b}$ \\
\hline Residual & 2094,450 & 106 & 19,759 & & \\
\hline Total & 6170,918 & 109 & & & \\
\hline
\end{tabular}

Sumber: Hasil Pengolahan Data Primer, SPSS for windows version 21.0

Berdasarkan Tabel diatas dapat kita lihat, bahwa seluruh tingkat signifikan antara masingmasing variabel $<0,050$, maka dapat disimpulakan bahwa secara simultan atau seluruh varibel berpengaruh positif dan siginifikan terhadap $\mathrm{Y}$.

\section{Implikasi Hasil Penelitian}

Berdasarkan hasil pengujian hipotesis diatas maka untuk meningkatkan kinerja Pegawai pegawai pada Dinas Kesehatan Kota (Dkk) Padang pimpinannya harus mampu meningkatkan :

1. Pengaruh Kepemimpinan Transformasional terhadap Kinerja Pegawai Pegawai.

Dimana dengan tingkat signifikan 0,000 lebih kecil dari 0,05. Maka diperoleh Ho ditolak dan Ha diterima, berarti secara parsial terdapat pengaruh positif dan signifikan Kepemimpinan Transformasional terhadap kinerja Pegawai pegawai. Hasil penelitian tersebut sejalan dengan penelitian yang dilakukan Garini, Ayu Putu Putri, et al. 2016 menunjukkan bahwa kepemimpinan transformasional berpengaruh signifikan terhadap kinerja Pegawai pegawai pada Pegawai Perusahaan Daerah Air Minum (PDAM) Kabupaten Jembrana, Bali.

2. Pengaruh Komunikasi Organisasi terhadap Kinerja Pegawai Pegawai.

Dimana dengan tingkat signifikan 0,048 lebih kecil dari 0,05. Maka diperoleh Ho ditolak dan Ha diterima, berarti secara parsial terdapat pengaruh positif dan signifikan Komunikasi Organisasi terhadap kinerja Pegawai pegawai. Hasil penelitian tersebut sejalan dengan penelitian yang dilakukan Anshari, Hairy, Et Al. 2014 menunjukkan bahwa Komunikasi Organisasi berpengaruh signifikan terhadap kinerja Pegawai pegawai pada Pegawai Bagian Sosial Sekretariat Daerah Kabupaten Kutai Timur.

3. Pengaruh Budaya Organisasi terhadap Kinerja Pegawai Pegawai.

Dimana dengan tingkat signifikan 0,000 lebih kecil dari 0,05. Maka diperoleh Ho ditolak dan Ha diterima, berarti secara parsial terdapat pengaruh positif dan signifikan Budaya Organisasiterhadap kinerja Pegawai pegawai. Hasil penelitian tersebut sejalan dengan penelitian yang dilakukan Dewi, Andi Ratna Sari. 2017 bahwa Budaya Organisasi berpengaruh poitif dan signifikan terhadap kinerja Pegawai pegawai pada Dinas Pertanian Kabupaten Mamuju. 
4. Pengaruh Kepemimpinan Transformasional, Komunikasi Organisasi, dan Budaya Organisasiterhadap Kinerja Pegawai Pegawai.

Dimana dengan tingkat signifikan 0,000 lebih kecil dari 0,05. Maka diperoleh Ho ditolak dan Ha diterima, berarti secara simultan terdapat pengaruh positif dan signifikan Kepemimpinan Transformasional, Komunikasi Organisasi, dan Budaya Organisasiterhadap Kinerja Pegawai Pegawai (Y). Hal ini sejalan dengan penelitian yang dilakukan oleh Penelitian yang di lakukan oleh Garini, Ayu Putu Putri , et al. 2016 menunjukkan Kepemimpinan Transformasional berpengaruh positif dan signifikan terhadap kinerja Pegawai pegawai. Sedangkan penelitian yang di lakukan oleh Anshari, Hairy, Et Al. 2014 menunjukkan bahwa Komunikasi Organisasi berpengaruh signifikan terhadap kinerja Pegawai pegawai. Dan penelitian yang di lakukan oleh Dewi, Andi Ratna Sari. 2017 bahwa Budaya Organisasi berpengaruh signifikan terhadap kinerja Pegawai pegawai.

\section{Kesimpulan}

1. Bahwa terdapat pengaruh positif dan signifikan antara Kepemimpinan Transformasional terhadap kinerja Pegawai pada Dinas Kesehatan Kota (Dkk) Padang. Dengan tingkat signifikan lebih besar dari alpha $(0,000<0,05)$, maka diperoleh $\mathrm{H} 0$ ditolak dan Ha diterima.

2. Bahwa terdapat pengaruh positif dan signifikan antara Komunikasi Organisasi terhadap kinerja Pegawai pada Dinas Kesehatan Kota (Dkk) Padang. Dengan tingkat signifikan lebih kecil dari alpha $(0,048<, 0,05)$, maka diperoleh $\mathrm{H} 0$ ditolak dan Ha diterima.

3. Bahwa terdapat pengaruh positif dan signifikan antara Budaya Organisasi terhadap kinerja Pegawai pada Dinas Kesehatan Kota (Dkk) Padang. Dengan tingkat signifikan lebih kecil dari alpha $(0,000<0,05)$, maka diperoleh $\mathrm{H0}$ ditolak dan Ha diterima.

4. Bahwa secara bersama-sama terdapat pengaruh yang signifikan antara Kepemimpinan Transformasional, Komunikasi Organisasi, dan Budaya Organisasi terhadap kinerja Pegawai pada Dinas Kesehatan Kota (Dkk) Padang. Dengan tingkat signifikan lebih kecil dari alpha $(0,000<0,05)$, maka diperoleh $\mathrm{H} 0$ ditolak dan Ha diterima.

\section{DAFTAR PUSTAKA}

Amirullah. 2015. Pengantar Manajemen. Jakarta: Mitra Wacana Media.

Muhammad, Arni. 2014. Komunikasi Organisasi. Jakarta: Bumi Aksara

Robbins,S.P dan Judge T.A. 2015. Perilaku Organisasi. Jakarta: Salemba Empat.

Sugiyono. 2014. Metode Penelitian Pendidikan Pendekatan Kuantitatif, Kualitatif,dan R\&D. Bandung: Alfabeta.

Umar, Husein. 2013. Metode Penelitian untuk Skripsi dan Tesis. Jakarta: Rajawali

Wibowo. 2013. Budaya Organisasi. Edisi Pertama. Jakarta: Rajawali Pers

Rivai, Veithzal. 2014. Manajemen Sumber Daya Manusia untuk Perusahaan, Edisi ke6, Depok : PT. Raja Grafindo Persada

Garini, Ayu Putu Putri , et al. 2016. Pengaruh Kepemimpinan Transformasional Dan Budaya Organisasi Terhadap Kinerja Pegawai Pada Perusahaan Daerah Air Minum (PDAM). e-Journal Bisma Universitas Pendidikan Ganesha Jurusan Manajemen (Volume 4 Tahun 2016)

Anshari, Hairy, Et Al. 2014. Pengaruh Komunikasi Organisasi Dan Budaya Organisasi Terhadap Kinerja Pegawai Bagian Sosial Sekretariat Daerah Kabupaten Kutai Timur. eJournal Administrative Reform, Volume 2, Nomor 4, 2014: 2483-2496

Dewi, Andi Ratna Sari. 2017. Pengaruh Gaya Kepemimpinan, Budaya Organisasi Dan Komitmen Organisasi Terhadap Kinerja Pegawai Dinas Pertanian Kabupaten Mamuju. JBMI Vol. 14 No. 2 Oktober 2017 